\title{
The Effect of Basel Criterias on Banking Profitability in Turkey: Analysis via Cointegration Method ${ }^{1}$
}

\author{
Erişah ARICAN \\ Professor \\ School of Banking and Insurance \\ Marmara University, İstanbul, Turkey \\ Başak TANINMIŞ YÜCEMEMIŞ \\ Professor \\ School of Banking and Insurance \\ Marmara University, İstanbul, Turkey \\ Levent ÇİNKO \\ Professor \\ School of Banking and Insurance \\ Marmara University, İstanbul, Turkey \\ Gökhan IŞIL \\ Associate Professor \\ School of Banking and Insurance \\ Marmara University, İstanbıul, Turkey \\ Ufuk ALKAN \\ Assistance Professor (PhD) \\ School of Banking and Insurance \\ Marmara University, İstanbul, Turkey \\ Kemal AKA \\ Research Assistant (PhD) \\ School of Banking and Insurance \\ Marmara University, İstanbul, Turkey
}

\begin{abstract}
New global financial regulations are implemented with respect to the developments in the financial system. A consideration of the place and significance of the Banking system globally and nationally that the importance of financial regulations regarding the system increases each day. In this respect Basel (Basel I, Basel II and Basel III criteria) reconciliation is conducted regarding the banking system. Especially to decrease the fragility of banks undertaking the role of financial mediators as a result of the global financial crisis in 2008, Basel II reconciliation has been expanded and BaselII criteria has been determined on 12.09.2010. Even though it is expected that Basel III reconciliation will be beneficial for the stability of the banking sector, it is expected that the long term profitability of banks will decrease in relation to the possible increase of their capital and liquidity. In this piece, Basel reconciliations are considered, its application in the Turkish banking sector is considered and by utilizing the data for 2002.Q4 and 2016Q.3, the effect of capital sufficiency ratio (CSR) of banks active in the Turkish Banking Sector via cointegration method determined by Basel reconciliation. As a result of the analysis in the long term an opposite relationship between loan risk, liquidity risk, CSR and bank profitability. Therefore, in Turkish banking sector, by applying Basel reconciliations financial and macroeconomic fragility of banks decrease however their profitability decreases. In this respect, it may be foreseen that against strong active and equity structure in face of low profitability rates, banks active in the Turkish banking sector are to compete in tougher conditions.
\end{abstract}

Keywords: Basel, Banking Sector, Via Cointegration Method

${ }^{1}$ Supported by Marmara University Scientific Research Projects Commission (Project No: SOS-A-100616-0302-Year 2016) 


\section{Introduction}

Banks are one of the most important actors among financial entities conducting mediation activity in the bank financial system. Crisis arising these days due to globalisation and increase in financial integration is affecting on a global level by a domino effect. Reasons such as financial systems or nations being weak and fragile, insufficient with respect to audit and observation, lack of good review of the risks they have taken may also cause an adverse effect due to financial crisis of banks.

Due to these negativities, Basel committee on Banking supervision active within Bank for International Settlements (BIS) has published the capital sufficiency reconciliation also known as Basel I in 1988(Basel Committee On Banking Supervision, 1988:1-30). In light of the needs of the market, market risks have also been included in the Basel I capital sufficient measure in 1996 (Basle Committee On Banking Supervision, 1996:1-11). However Basel II criteria has been accepted in 2004 due to the reasons that Basel I criteria is subject to a single measure for the valuation of the capital sufficiency, principles are weak for the valuation of the capital sufficiency, classification, lack of variation of loans and unforeseeable fast changes in secondary markets and derivative markets(Basel Committee On Banking Supervision, 2004:1-257). However, the global financial crisis which has begun at the end of 2007 in the United States of America and expanding over the globe fastly -also known as the mortgage crisis- Basel II criteria has been subject to discussion shortly after its acceptance. As a result of these discussions, on 12 September 2010, Basel II criteria has been determined (Basel Committee on Banking Supervision, 2010:1-7). These criteria are mainly based on Basel II criteria and are making additions to Basel II criteria with respect to content of equity calculation of capital and liquidity ratio. These regulations made within the framework of Basel III bring additional liability on banks regarding capital sufficiency of banks and liquidity.

In the work carried out, criteria accepted with Basel I, Basel II and Basel III have been explained the effect of CSR determined as a result of these criteria on profitability of banks active in the Turkish banking sector, economically by way of cointegration method.

\section{General Framework of Basel Reconciliation}

\subsection{Basel I Reconciliation}

Capital Sufficiency Reconciliation has been published in 1988 also known as Basel I by the Basel Banking Audit Committee active under BIS to enable banking audits to be more understandable, developed and alignment of national capital sufficiency calculation methods with one another. With the Basel I reconciliation, a mutual calculation of capital sufficiency has been carried out globally in many nations' banking sectors (Basel Committee on Banking Supervision, 1988:1).

Basel Committee decisions do not include a legal liability with respect to binding nations however, are generally accepted by nations with its suggestion nature. Furthermore, Basel committee suggestions are taken into consideration in the regulations and works carried out by the European Parliament and Council (Basle Committee On Banking Supervision, 1988:2).

Whilst only loan risk is considered for the calculation of banking capital sufficiency in Basel I criteria, due to the adverse effect of instability in banking market in 1990's market risk has also been included in the calculation of capital sufficiency in 1996. It has been intended to strengthen banks against economic crisis and financial fragility by the addition of market risk. Basically with Basel I reconciliation, it has been intended for the banks to move within a certain criteria framework whilst giving out loans and not carry out risks transactions over a determined risk threshold (Basle Committee On Banking Supervision, 1996:7-8).

The lower limit of "ratio of capital to risky actives" which is considered as the international capital sufficiency standard in Basel I reconciliation has been set at $8 \%$. Thereby, it is necessary for banks that will give out loans to have at least $8 \%$ of it as capital. In other words, a bank willing to issue a loan shall be entitled to allot loans at most up to 12.5 times the total capital (Basle Committee On Banking Supervision, 1988:28). In order to issue more risky loans, it has become necessary for banks to increase their capital. As a result of these discussions the This brings additional costs on to the banks.

\subsection{Basel II Reconciliation}

It has been argued that Basel I criteria is subject to a single measure for the valuation of the capital sufficiency, principles are weak for the valuation of the capital sufficiency, classification, lack of variation of loans and unforeseeable fast changes in secondary markets and derivative markets. Therefore the Basel II criterion has been accepted in 2004 to replace Basel I criteria accepted in 1988. 
With Basel II reconciliation a capital sufficiency calculation has been adopted which is not a single kind calculation but a method which is adaptable to the economic circumstances and conditions of the nations. Basel II reconciliation is a method wider in scope by adding legal equity needs into risk calculation. One of the most important measures adopted by the utilization of the Basel II reconciliation is that each of the clients are being subjected to the same risk rating. Banks shall be entitled to carry out different ratings for customers under different risk groups by the loan rating entities. Also with the Basel II reconciliation, for the capital sufficiency calculation, it is suggested to utilize new calculation methods including loan, market and operational risks. One of the novelties brought by Basel II reconciliation is that the activity of the entities carrying out audit and review duties in the banking system are enhanced and that the public is periodically and correctly informed by these entities (Basel Committee On Banking Supervision, 2004:52).

With Basel II criteria, operational risks has been added to equity definitions, loan risk and market risk used in minimum capital need calculation in Basel I criteria.

As a result of such addition capital sufficiency is calculated with the below method in Basel II criteria(Basel Committee On Banking Supervision, 2004:53):

$$
\left(\frac{\text { Equity }}{\text { Risky actives }+[\text { (Market Risks }+ \text { operational Risks) } x 12,5]} \geq 8 \%\right.
$$

Addition of operational risk to capital sufficiency calculation forces the banks to be more selective and diligent whilst giving out loans. Therefore even though it is expected that the loan volumes of banks will decrease, decrease in loans will adversely affect the profitability of banks.

Table 1 shows the alternative measurement methods in Basel II criteria. With Basel II criteria the loan risk calculation methods have been varied. Thereby in addition to standards risk measurement methods "Basic Internal Rating Method" and "Developed Internal Rating Methods" have been implemented(Basel Committee On Banking Supervision, 2004:48). Basic Internal Rating Method is; calculation of financial entities by way of utilizing internal rating models provided that the default possibility of risky assets are also calculated. Developed internal rating method is; financial entities determining internally the default possibility and losses in case of default and default amounts by them.

Table 1: Alternative Measurement Methods Under the BaselII Criteria

\begin{tabular}{|c|c|c|c|}
\hline $\begin{array}{l}\text { DEVELOPMENT } \\
\text { LEVEL }\end{array}$ & $\begin{array}{l}\text { MARKET RISK (1996 } \\
\text { Changes) }\end{array}$ & LOAN RISK & OPERATIONAL RISK \\
\hline SIMPLE & - & $\begin{array}{l}\text { Simplified Standard } \\
\text { Approach (SSA) }\end{array}$ & Basic Indicator Approach \\
\hline INTERMEDIATE & Standard Approach & Standard Approach & $\begin{array}{l}\text { Alternative Standard Approach } \\
\text { - Standard Approach }\end{array}$ \\
\hline \multirow{2}{*}{ DEVELOPED } & \multirow{2}{*}{ Value approach subject to risk } & $\begin{array}{l}\text { Basic Internal Rating } \\
\text { Method (BIRM) }\end{array}$ & \multirow{2}{*}{ Advances measurement approach } \\
\hline & & $\begin{array}{l}\text { Developed Internal Rating } \\
\text { Method (DIRM) }\end{array}$ & \\
\hline
\end{tabular}

Source: Yüksel., Ayhan, (2005). Basel II'nin KOBİ Kredilerine Muhtemel Etkileri. BDDK Araştırma Yayınları, p.25.

Standard Approach used in the measurement of market risk is; the rating of treasury and central banks and financial entities of nations being rated by external independent loan rating entities. Loan rating used herein is basically measurement of the main receivable and interest liabilities of the debtor and capacity of the debt being paid in time and fully. Whilst carrying out loan rating, objectivity, independence, transparency and holding sufficient amount of information has been adopted. With the Basel II reconciliation, loan rating notes and default possibility rates provided by international loan rating entities such as Standart \& Poor's and Moody's has been adopted (Basel Committee On Banking Supervision, 2004:37). For loan risk in simplified standard approach risk weight is determined by export loan entities (Basel Committee On Banking Supervision, 2004:24).

One of the mostly adopted methods in market risk calculation Value at Risk-VaR approach is, defined as during a certain timeframe and probability, the highest loss that may occur in a financial asset or portfolio value. In other words, $\mathrm{VaR}$ is the highest loss of value calculated with a certain probability statistically of assets kept in a portfolio for a certain term (Chen, 2014:186). 
Table 2: Risk Weight Utilized in Standard Approach (\%)

\begin{tabular}{|c|c|c|c|c|c|c|c|}
\hline ASSETS & OPTIONS & AAA/AA- & $\mathrm{A}+/ \mathrm{A}-$ & BBB+/BB- & BB+/B- & $\begin{array}{c}\text { BELOW } \\
\text { B }\end{array}$ & $\begin{array}{c}\text { NON- } \\
\text { RATED }\end{array}$ \\
\hline $\begin{array}{c}\text { Loans granted to } \\
\text { treasury/central } \\
\text { banks } \\
\end{array}$ & $\begin{array}{c}\text { As per } \\
\text { independent } \\
\text { loan rating note } \\
\end{array}$ & 0 & 20 & 50 & 100 & 150 & 100 \\
\hline \multirow{3}{*}{$\begin{array}{l}\text { Loans granted to } \\
\text { other public } \\
\text { bodies and entities }\end{array}$} & $\begin{array}{l}\text { Similary to } \\
\text { Treasury } \\
\end{array}$ & 0 & 20 & 50 & 100 & 150 & 100 \\
\hline & Option-1 & 20 & 50 & 100 & 100 & 150 & 100 \\
\hline & Option -2 & 20 & 50 & 50 & 100 & 150 & 20 \\
\hline \multirow{3}{*}{$\begin{array}{c}\text { Loans granted to } \\
\text { Banks }\end{array}$} & Option -1 & 20 & 50 & 100 & 100 & 150 & 100 \\
\hline & Option -2 & 20 & 50 & 50 & 100 & 150 & 50 \\
\hline & $\begin{array}{c}\text { Option -2 Short } \\
\text { term due }\end{array}$ & 20 & 20 & 20 & 50 & 150 & 20 \\
\hline \multirow[t]{2}{*}{$\begin{array}{c}\text { Loans granted to } \\
\text { Companies } \\
\end{array}$} & - & 20 & 50 & 100 & - & 150 & 100 \\
\hline & \multicolumn{7}{|c|}{ RISK WEIGHT } \\
\hline Retail Loans & \multicolumn{7}{|c|}{75} \\
\hline $\begin{array}{c}\text { Residency } \\
\text { Purposed } \\
\text { Immovable Loans } \\
\end{array}$ & \multicolumn{7}{|c|}{35} \\
\hline $\begin{array}{c}\text { Receivables } \\
\text { Subject to } \\
\text { Enforcement } \\
\text { Proceedings } \\
\end{array}$ & \multicolumn{7}{|c|}{ As per certain conditions $\% 50, \% 100$ or $\% 150$} \\
\hline
\end{tabular}

Source: Yayla, Münür ve Yasemin Kaya, (2005), Basel II. Ekonomik Yansımaları ve Geçiş Süreci, BDDK ARD Çalışma Raporları, p.3.

As per the risk weights used in standard approach (refer to Table 2), risk weight calculation of the creditors of banks of treasury and central banks will be determined by the note to be established by the external rating entities of these entities. However a bank will use the risk weight determined by the nation's own "Audit Authority" for loal currency receivables (for Turkey- Banking Regulation and Supervision Agency (BRSA). For foreign currency receivables, the risk weights provided in Table 2 should be utilized. Thereby, while the credit note of the nation decreases, it requires that for the foreign currency receivables of these banks from treasury and central banks a higher risk weight should be applied. This causes a high level capital sufficiency problem in banks.

For credits loaned to banks as per Basel II reconciliation two options are offered which may be chosen by the nations' own audit authority. In the first option, the risk weights of the nation will be increased by one rate. In the second option, risk weifht shall be determined as per the credit rating of the counter party bank. Also in the second option for receivables with less than three month due dates provided that their risk weight is limited by the $20 \%$ lower limit, the bank credit rate equivalent risk weight decreased by one rate can be applied.

\subsection{Basel III Reconciliation}

Basel III reconciliation has been the subject matter of discussion after the bankruptcy of the Lehman Brothers in the USA in September 2008 and starting of big bank and investment companies internationalisation and expanding of the Global Financial Crisis globally. As a result of such discussions Basel Committee has announced new reforms in the banking sector in 12 September 2010 also known as Basel III. Reforms brought in by Basel III include additional liabilities for the purpose of bank specific precuations and management of systematic risks aiming to decrease the adverse effects of the crisis and expanding of the crisis.

Basic aims of BaselIII reconciliation;

- Strengthening of banks against financial and economic crisis,

- Development of corporate management and risk management applications applied in financial entities,

- Enhancement of the transparency of financial entities (Basel Committee On Banking Supervision, 2010:1-2). 
In order to achieve the aforementioned goals with the BaselIII reconciliation certain foundational changes have been foreseen. These changes are;

- Increase in the quantity of current minimum capital and changes in their quality,

- Bringing capital necessity standard which are not risk based,

- Capital requirement of banks to be held may be increased decreased as per the economic status,

- Regulations as per liquidity ratios,

- Counter party credit risk calculation (Basel Committee On Banking Supervision, 2010:3-5).

Scope of the equity under Basel II has been changed with the Basel III reconciliation. Core capital which has been taken into consideration with Basel III and with its method provided below; is defined as capital under Tier 1 and consisting of items with high loss coverage potential. It has been aimed to increase the minimum core capital between the years $2013-2015$ from $2 \%$ to $4.5 \%$ (please refer to Table 3 ).

$$
\text { Core Capital Rate }=(\text { Core Capital } / \text { Risky Assets })
$$

Another novelty brought by the Basel III reconciliation is the capital protection buffer. In the capital protection buffer, core capital is added to the Tier 1 capital and total capital gradually. It is aimed to increase this rate gradually as of 2019 by $2.5 \%$. In the event that this rate is not covered bank will carry out its activities however will be subject to certain limitations while taking capital distribution decision.

During the global financial crisis term it has been observed that the Basel II criteria has been insufficient regarding the high leverage ratio transactions carried out by financial entities. Therefore, one of the novelties brought in by Basel III criteria has been regarding the leverage rates. Through Basel III a minimum no-risk rate has been established between off-balance sheet items and main capital with total actives. Tier 1 capital leverage rate has been determined as at least 3\% for the term 2013-2017 also known as the application period. With this rate, it is allowed for the banks to create a turnover of up to 33 times its main capital as of the year 2018 (Basel Committee On Banking Supervision, 2010:3-5). With respect to the criticism brought in relation to the Basel II reconciliation circularity, circular capital buffer application has been adopted. It is aimed to prevent fast credit increase changed by the economic increase rate independent from the core capital by way of circular capital buffer. One of the most important novelties brought in by the Basel III reconciliation is on the liquidity rates. Two new liwuidity ratio applications have been aimed named Liquidity Coverage Ratio and Net stable Funding Ratio. Liquidity Coverage Ratio is calculated by the dicision of the liquidity assets of banks within 30 days by the net increases. Liquidity coverage rate should be at least $100 \%$. Net stable funding rate is obtained by the division of the current stable funding amount to the needed stable funding amount. Current stable funding amount is determined as per the due date and quality of the items in the passives of the bank including primary and secondary capital. Needed funding amount is calculated as per the due date and quality of the items in the actives of the bank including primary and secondary capital. It is aimed to strenghten the mid and long term passive structure of banks via the net stable funding rate.

Table 3: Criteria Accepted by BaselIII Reconciliation (\%)

\begin{tabular}{|l|c|c|c|c|c|c|c|}
\hline & $\mathbf{2 0 1 3}$ & $\mathbf{2 0 1 4}$ & $\mathbf{2 0 1 5}$ & $\mathbf{2 0 1 6}$ & $\mathbf{2 0 1 7}$ & $\mathbf{2 0 1 8}$ & $\begin{array}{c}\text { As of 1 } \\
\text { Janıary 2019 }\end{array}$ \\
\hline Core Capital Sufficiency Rate & 3,50 & 4,00 & 4,50 & 4,50 & 4,50 & 4,50 & 4,50 \\
\hline Capital Preservation Buffer & - & - & - & 0,625 & 1,25 & 1,875 & 2,50 \\
\hline $\begin{array}{l}\text { Total of Core Capital Sufficiency } \\
\text { Rate and Capital protection Buffer }\end{array}$ & 3,50 & 4,00 & 4,50 & 5,125 & 5,75 & 6,375 & 7,00 \\
\hline $\begin{array}{l}\text { Value Decreased from the Core } \\
\text { Capital }\end{array}$ & - & 20,00 & 40,00 & 60,00 & 80,00 & 100,00 & 100,00 \\
\hline Main Capital Sufficiency Rate & 4,50 & 5,50 & 6,00 & 6,00 & 6,00 & 6,00 & 6,00 \\
\hline Capital Sufficiency Rate (CSR) & 8,00 & 8,00 & 8,00 & 8,00 & 8,00 & 8,00 & 8,00 \\
\hline $\begin{array}{l}\text { Capital Sufficiency Rate and Capital } \\
\text { Preservation Buffer Total }\end{array}$ & 8,00 & 8,00 & 8,00 & 8,625 & 9,25 & 9,875 & 10,50 \\
\hline $\begin{array}{l}\text { Value Decreased from the Main } \\
\text { Capital and Additional Capital }\end{array}$ & \multicolumn{7}{|l|}{ To be decreased gradually for ten years starting from the year 2013. } \\
\hline
\end{tabular}

Source: Basel Committee On Banking Supervision, (2010), Press Release, BIS, p.7 


\section{Basel Reconciliation Application on the Turkish Banking Sector}

Legal regulations have been implemented on 26 October 1989 regarding the application of the Basel I reconciliation resolutions of 1988 in the Turkish Banking Sector (Official Gazette, 1989, No 20324:14-17). With this regulation the terms regarding "Capital Base / Risk Weightes Assets", "Non-Cash Credits" and "Liability Standard Ratio"to be applied against the potential risks of banks active in the Turkish banking sector have been provided. As one of the first nations to implement legal regulations regarding the application of Basel I criteri, gradual changes have been made in standards in Turkey since 1989 and it has been planned to set the capital sufficiency ratio at minimum 8\% as of 1992 at the end of financial term. With the Comminuqé implemented by the Principality Treasury Office on 9 February 1995, it has been adopted that the capital sufficiency ratio calculated at the end of the term to be calculated by three month periods. Furthermore, in this Communiqué it has been decided to implement two new ratio calculations "Additional Capital Main Capital Ratio" and "Obtained Capital Similar Loans to Main Capital"(Official Gazette, 1995, No 22197:17-25).

Between years 1994-1999 corresponding to the years when the Basel I reconciliation has been applied, due to reasons such as economic crisis and structural problems, 11 banks have been transferred to the Saving Deposits Insurance Fund (SDIF) (http://www.tmsf.org.tr/intikaleeden.bankalar.tr).In this term a scattered regulation and audit system had been set in place in the banking system consisting of the Treasury, Central Bank and SDIF. In order to solve these structural provlems and enable an active regulation and audit in the system BRSA has been established in 1999 and has become active in September 2000. After the formation of the BRSA with respect to the capital sufficiency calculation, "The Regulation on the Measurement and Evaluation of the Capital Sufficiency of Banks" has been published in February 2001. With this regulation in addition to the previous capital sufficiency measurement market risks have been included in the capital sufficiency measurement and consolidated and non-consolidated capital sufficiency has started to be measured each day.

Certain works have been carried out in the Turkish Banking Sector after the Basel II reconciliation accepted by the Basel Committee on 2004 and in 2007 BRSA has added an operational risk on to the credit and market risk of the capital sufficiency measurement (Aykut, 2008:8). Due to the financial crisis expanding globally as of 2008 the implementation of Basel II criteria in Turkey has also been postponed (BDDK, 2008:1).BRSA has decided in 2011 with the resolution numbered 4099 on the application route of the Basel II criteria and as per this resolution for the term between 01.07.2011 and 30.06.2012 in order to enable better harmonisation banks and customers in this term banks' capital sufficiency calculation had to be reported to the BRSA only. In this term banks' harmonization with the new criteria has only been observed by the BRSA. At the end of this transitional period as of 1 July 2012 Basel II criteria has begun to be applied in the Turkish banking sector.

In the Turkish Banking sector in relation to harmonization with the criteria of Basel reconciliations, legal regulations have been applied before many other nations. Especially as of 2000 Turkish Banking system has taken many important steps together with BRSA. Whilst legal regulations are implemented in the Turkish banking sector on the other hand capital sufficiency rates have been achieved at a higher level than the criteria established by many other nations.

\section{Graph 1: Turkish Banking Sector Capital Sufficiency Ratio (\%)}

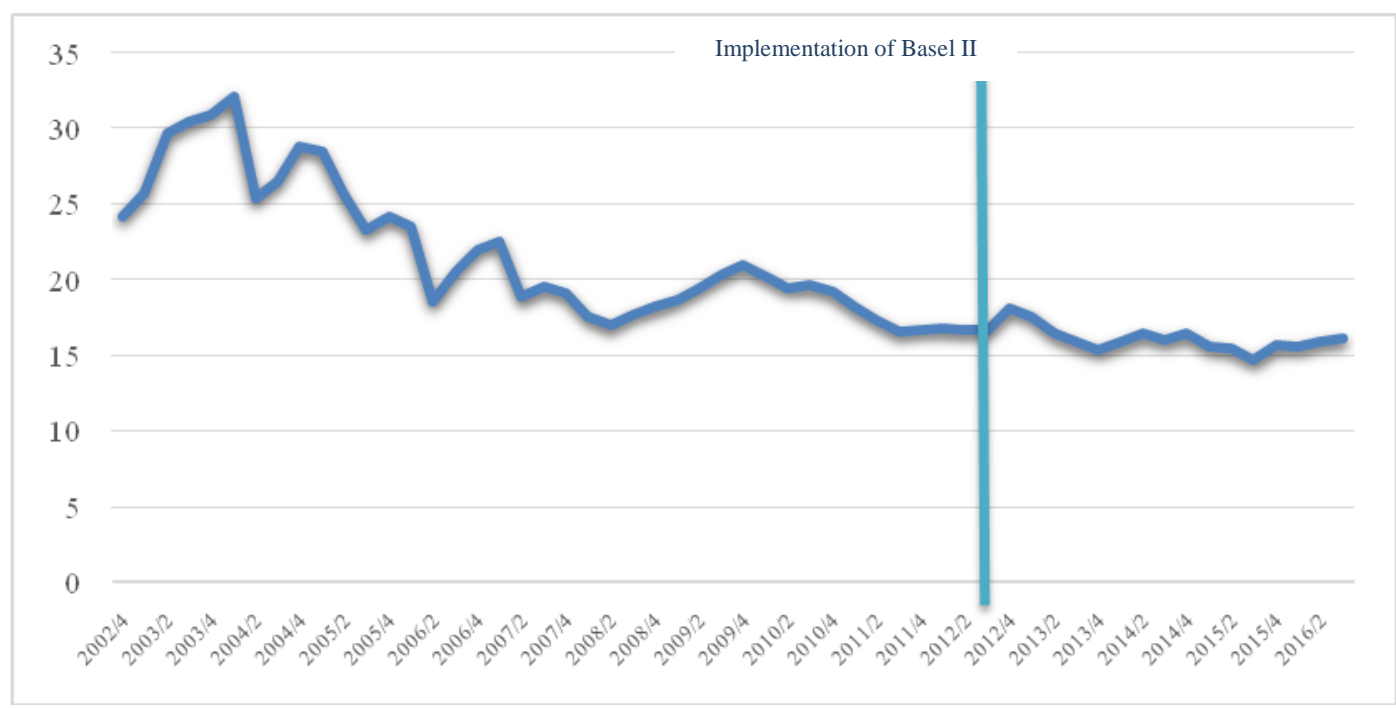

Source: BRSA data used and prepared by us. 
Even though CSR has been set at 8\% with Basel II criteria, the legal limitation to BRSA's CSR application in Turkey has been established at 12\% (BDDK, 2010:s.12). As seen in Graph 1, between the year 2004 and 2012 when the Basel II criteria begun to be applied, the capital sufficiency of the Turkish Banking sector has been above the legal limitation set by Basel criteria and BRSA. As of September 2016 the capital sufficiency of the Turkish banking sector has been calculated as $16.04 \%$.

After the global financial crisis as per the needs of the banking sector, Basel III criteri has been determined by the Basel Committee. For the harmonization of the Basel III criteria determined by the Basel Committee, BRSA published "The Regulation on the Measurement and Evaluation of the Capital Sufficiency of Banks" and "Regulation on Bank Equity" published in the Official Gazette on 05.09.2013 and numbered 28756 no changes have been made to the minimum CSR at $8 \%$ however for lower ratios changes have been made. With such changes as the minimum threshold of $8 \%$ ratio minimum core capital sufficiency ratio has been determined by $4.5 \%$ and the minimum main capital sufficiency ratio has been determined at 6\%. In light of the regulations the Core Capital Ratio which has been applied as of January 2014 has shown a raise by $12.73 \%$ as of January 2014, has begun to increase after September 2015 even though it has shown a decrease between November 2014 and September 2015. Core Capital ratio has increased up to $13.22 \%$ as of December 2016 (Please refer to Graph 2).

\section{Graph 2: Core Capital Ratio}

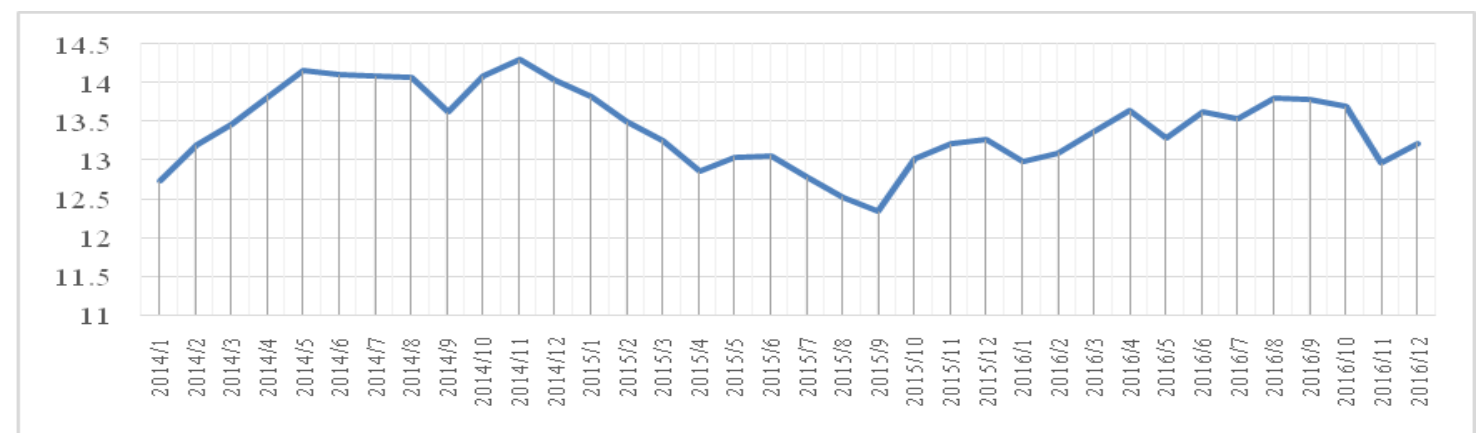

Source: BRSA data used and prepared by us.

Upon a review of the "Net Term Profit/Total Avtices" ratio (Return on Asset-ROA) showing the active profitability of the Turkish banking sector, in the year 2004 the active profitability has been realized as $2.39 \%$ in the Turkish banking sector. After the year 2004 RoA has shown a general decrease, it has degressed to $0.88 \%$ as of the year 2015. Between the years 2004-2015 when the Basel criteria wsa applied in the Turkish banking sector RoA had decreased. Especially after the year 2012 whereby the Basel II criteria was applied ROA of banks decreased even faster. Due to the fact that new obligations have been established on banks with respect to capital sufficiency banks have begun to keep additional capital, being more selective when granting loans and limiting risky loans to avoid problems at CSR's. It can be argued that Basel criteria application affected the decrease in banking profitability in the Turkish banking sector.

Upon a review of the "Net Term Profit/Equity" ratio (Return on Equity-ROE) showing the equity profitability of the Turkish banking sector, in the year 2004 the equity profitability has been relaized as $11.85 \%$ in the Turkish banking sector. After the year 2004 just like RoA, ROE has shown a general decrease, it has degressed to $8.05 \%$ as of the year 2015 as can be seen in Graph 3. Between the years 2004-2015 when the Basel criteria was applied in the Turkish banking sector RoE had decreased just like ROA. It is again argued that Basel criteria application affected the decrease in equity profitability in the banking sector.

\section{Graph 3: Turkish Banking Sector Profitability}
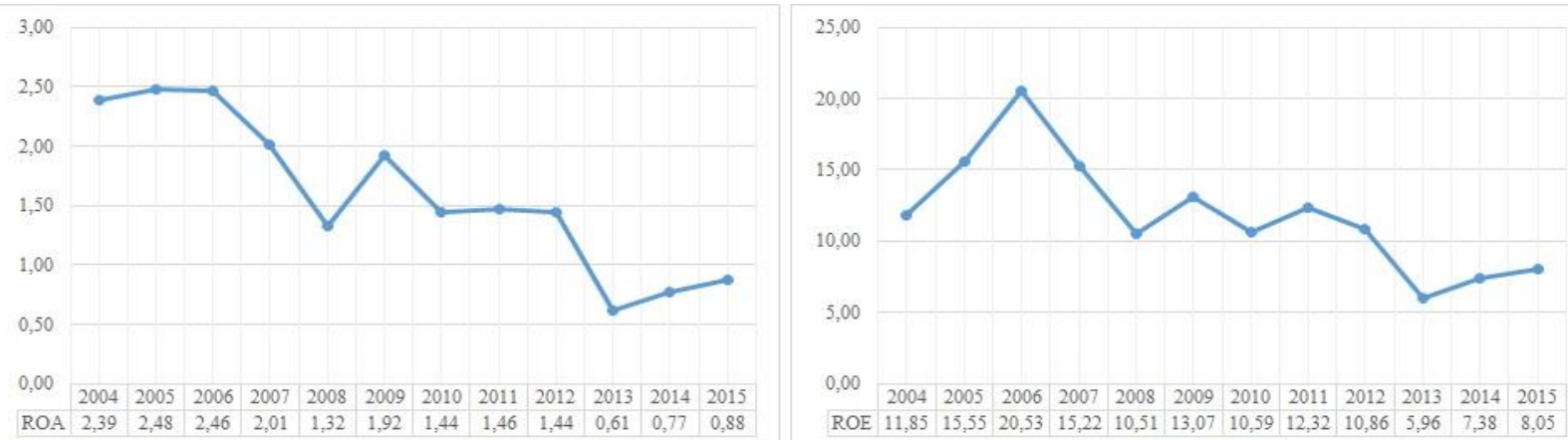

Source: Turkish Bank Union (TBU) data used and prepared by us. 


\section{Econometric Method and Empirical Findings}

\subsection{Purpose, Method of Application and Used Variables}

With the fastidious change of economic integration in the world, the probability of one crisis in a nation effecting other nations has increased. Therefore in our day nations do not only get affected by internal but also external crisis. It is seen especially recently that economic sequences are breaking due to crisis and shocks. Thereby in econometric analysis where structural breaking is not considered the results may be misleading. It may be wrong that sequences have been stable in unit root test predictions without taking into consideration of the periods with breaks. In a nation with structural changes, structural qualities of economic indicators can change, in this case the unification level may also change. Unit root tests taking structural breaks' existence and cointegration tests are varied allowing single, double and/or more breaks. In this study single break allowing tests have been used. Because in Turkey changes to CSR with Basel II has begun on 01.07.2011 and full application to Basel II was realized on 01.07.2012 a year later. It is especially predicted that Basel II application which is bringing significant capital sufficiency has effect on banking profitability. Furthermore a short term after the application of Basel II in Turkey Basel III reconciliation has been accepted by the Basel Committee. Turkish banking sector has fastly harmonized with the Basel III reconciliation even though Basel II reconciliation had just been implemented. The purpose of this study is to define the relationship between capital sufficiency and profitability variables as of the year 2012 in the Turkish Banking sector and to show the structural change in the sector in the same year via econometric methods. Thereby by analysing whether there is a periodic change through a single break unit root test, establishing the relationships through cointegration test. In this work 2002.Q4-2016.Q3 period quarter data has been considered.

Table 4: Definitions Regarding The Variables Used İn The Research

\begin{tabular}{ll}
\hline Variables & \multicolumn{1}{c}{ Definitions } \\
\hline Dependent Variable & \\
\hline ROA & Active Profitability of the Banking Sector (Net Term Profit/ Total Actives) \\
ROE & Equity Profitability of the Banking Sector (Net Term Profit/ Equity) \\
\hline Independent Variables & \\
\hline SYR & Capital Sufficiency Ratio \\
GAP & Liquidity Risk((Credits and Receivables-Acquired Funds)/Total Assets) \\
KR & Credit Risk (Credits subject to enforcement proceedings/Total credits) \\
\hline
\end{tabular}

Independent variables effecting the profitability (ROA and ROE) of banks active in the Turkish banking sector are capital sufficiency (CSR) credit risk (Credits subject to enforcement proceedings/Total credits) and Liquidity Risk ((Credits and Receivables-Acquired Funds)/Total Assets). Definitions regarding variables have been provided in Table 4.

As a first step in order to analyse the stability of the sequences Zivot-Andrews structural breaking unit root test has been applied. In the second step, the long term relationship between said variables have been reviewed with the Gregory-Hansen structural break cointegration. Lastly long and short term cointegration multiples have been provided.

\subsection{Zivot-Andrews Structural Breaking Test}

Stability showing that the average, variation and auto-covariation of a time sequence does not change in different timeframes are important as they do not reveal the fake relationship between the sequences and prevent the permanency of the effect of a shock.

Structural changes emerging from reasons such as crisis and shocks cause structural changes in economic indicators and where structural changes are not taken into consideration the results belonging to econometric methods may be misleading. Zivot-Andrews (1992) test has been developed as an alternative to the Perron (1989) test allowing structural breaks and external consideration of structural breaks. Zivot-Andrews (ZA) allows structural break and unit root test is predicted based on three models. In models considered for the ZA unit root test; Model A represents levelled, Model B represents inclined and Model C represents both inclined and levelled structural changes. In the equations numbered (1),(2) and (3) below explanations regarding Model A, Model B and Model C are provided (Zivot and Andrews, 1992:254).

$$
\begin{aligned}
& \text { Model A: } y_{t}=\mu+\beta_{t}+a y_{t-1}+\theta D U(\varphi)+\sum_{i-1}^{k} c_{t} \Delta y_{t-1}+e_{t} \\
& \text { Model B: } y_{t}=\mu+\beta_{t}+a y_{t-1}+\theta_{2} D T(\varphi)+\sum_{i-1}^{k}+e_{t}
\end{aligned}
$$


Model C: $y_{t}=\mu+\beta_{t}+a y_{t-1}+\theta_{2} D T(\varphi)+\theta_{1} D U(\varphi)+\sum_{i-1} c_{1} \Delta y_{t-1}+e_{t}$

$t=1,2 \ldots, T$ provided in equations represents time, $T_{B}$ re presents breaking time, $\tau=T_{B} / \mathrm{T}$ shows the breaking point. Furthermore, $D U_{t}$ shows the average breaking and $D T_{t}$ trend break variable. Explanations are provided below regarding these variables:

$D U_{t}=1 \quad t>T_{B} \quad D T_{t}=t-T_{B} t>T_{B}$

$D U_{t}=0$ diğer $D T_{t}=0$ diğer

For the application of the ZA test firstly Model $\mathrm{C}$ is predicted and the suitable model is chosen as per the meaning of parameters belonging to DU and DT shadow variables. In the event that both DU and DT shadow variables are statistically meaningful Model C's prediction should be appropriate. On the other hand only DU being appropriate shows that Model A and DT being appropriate shows that Model B is appropriate. In practice mostly Model A and Model C are preferred (Yavuz, 2006:166-167). In this test the date on the model with the lowest t-statistic of the coefficient of the $\mathbf{y}_{\mathrm{t}-1}$ variable represents the appropriate structural breaking point. After the determination of the appropriate breaking point, the calculated t-statistic should be compared with the ZA critical values. Zero hypothesis of the test shows that the sequence has a unit root without a structural break; alternative hypothesis shows that the sequenc is stable with the structural break. In the event that the calculated t statistic is lower than the table critical value as determined by Zivot-Andrews, zero hypothesis where the sequence has a unit root is rejected and in this case the alternative hypothesis stating that the sequence has a unit root and is stable with the structural break is accepted. Length of delay is determined by the Schwatz Criteria and has been provided in parenthesis.

Table5: Zivot-Andrews Test Results

\begin{tabular}{|c|c|c|c|c|}
\hline Variables & $\begin{array}{l}\text { Model A } \\
(\text { min. t-ist) }\end{array}$ & Model A Breaking Time & $\begin{array}{l}\text { Model C } \\
\text { (min. t-ist) }\end{array}$ & \begin{tabular}{|lll}
$\begin{array}{l}\text { Model } \\
\text { Time }\end{array}$ & C & Breaking \\
\end{tabular} \\
\hline KR & $-4.296(1)$ & 2012.Q1 & $-4.062(1)$ & 2012.Q1 \\
\hline GAP & $-3.852(0)$ & 2012.Q1 & $-4.223(0)$ & 2012.Q1 \\
\hline SYR & $-4.027(1)$ & 2012.Q1 & $-4.507(1)$ & 2012.Q1 \\
\hline $\mathrm{ROA}$ & $-3.113(1)$ & 2012.Q2 & $-3.284(1)$ & 2012.Q2 \\
\hline \multirow[t]{2}{*}{ ROE } & $-4.375(0)$ & 2012.Q2 & $-4.278(0)$ & 2012.Q2 \\
\hline & \multicolumn{2}{|c|}{ Model A Critic Values } & \multicolumn{2}{|c|}{ Model C Critic Values } \\
\hline \multirow{3}{*}{$\begin{array}{l}\text { Critic Values } \\
\text { Critic Values }\end{array}$} & & -5.724 & \multicolumn{2}{|r|}{-5.621} \\
\hline & & -4.996 & \multicolumn{2}{|r|}{-5.085} \\
\hline & & -4.732 & \multicolumn{2}{|r|}{-4.892} \\
\hline
\end{tabular}

Test statistical values of Model A and Model C have been found to be less than the critical rate as per the absolute rate. Therefore the variables considered for Model A and Model $\mathrm{C}$ have become appropriate on the 1\%, 5\% and 10\% appropriateness levels and their break dates have been determined. In this case the zero hypothesis has been rejected and the alternative hypothesis has been accepted. Zero hypothesis of the test shows that the sequence has a unit root without a structural break and alternative hypothesis shows that the sequence is stable with the structural break. With the ZA test results the structural change in the Turkish banking system in the year 2012 has been provided. In consideration of the first degree differences of the sequences, provided that the structural breaks are also considered, the sequences have been determined to be stable. Therefore for cointegration the first degree differences have been obtained and worked in relation thereto.

\subsection{Gregory-Hansen Cointegration Test}

In this work the cointegration test developed by Gregory and Hansen (1996) will be applied which allows the single structural break after the unit root test allowing the single structural break. Cointegration method of Gregory and Hansen (1996) is a test determining the structural break internally and allowing a single structural break. The long-term relationship between sequences can be determined in the cointegration test through three different models. Model 1 means break at stable $(\mathrm{C})$, Model 2 represents break at trendy stable $(\mathrm{C} / \mathrm{T})$ and Model 3 represents change in regime. Explanations regarding Model 1, Model 2 and Model 3 are provided below (Gregory and Hansen,1996:103). 
Model 1: $y_{1 t}=\mu_{1}+\mu_{2} \varphi_{t r}+\alpha^{T} y_{2 t}+\varepsilon_{t}$

Model 2: $y_{1 t}=\mu_{1}+\mu_{2} \varphi_{t r}+\beta t+\alpha^{T} y_{2 t}+\varepsilon_{t}$

Model 3: $y_{1 t}=\mu_{1}+\mu_{2} \varphi_{t r}+\alpha_{1}^{T} y_{2 t}+\alpha_{2}^{T} y_{2 t} \varphi_{t r}+\varepsilon_{t}$

In these equations $\mu_{1}$ and $\mu_{2}$ are the same as the model showing break at stable. In Model $3 \alpha_{1}$ shows the inclination coefficient before the break; $a_{2}$ shows the changes in the inclination coefficient after the break (Gregory and Hansen, 1996:103).

Test statistics determined for the appropriate model in this test should be compared with the critical values table provided in the work of Gregory and Hansen (1996). Thereby a hypothesis is tested showing the cointegration relationship arising with structural break against the basic hypothesis showing that there is no cointegration relationship between the variables.

Table 6: Gregory-Hansen Cointegration Test Results

\begin{tabular}{|c|c|c|c|c|}
\hline \multirow[t]{2}{*}{ Model (dependent variable ROE) } & \multirow{2}{*}{$\begin{array}{c}\text { Breaking } \\
\text { Term }\end{array}$} & \multirow[t]{2}{*}{ ADF Statistic } & \multicolumn{2}{|c|}{ Critical Value } \\
\hline & & & $\% 1$ & $\% 5$ \\
\hline Breaking at stable (C) & 2012.Q1 & $-4.321(1)$ & $\begin{array}{l}-5.823 \\
\end{array}$ & -5.321 \\
\hline Breaking at stable and trend $(\mathrm{C} / \mathrm{T})$ & 2012.Q1 & $-4.116(1)$ & -6.059 & -5.632 \\
\hline Regime Change (C / S) & 2012.Q1 & $-4.623(1)$ & -6.517 & -6.044 \\
\hline \multirow[t]{2}{*}{ Model (dependent variable ROA) } & \multirow{2}{*}{$\begin{array}{c}\text { Breaking } \\
\text { Term }\end{array}$} & \multirow[t]{2}{*}{ ADF Statistic } & \multicolumn{2}{|c|}{ Critical Value } \\
\hline & & & $\% 1$ & $\% 5$ \\
\hline Breaking at stable $(\mathrm{C})$ & 2012.Q1 & $-4.226(1)$ & -5.823 & -5.321 \\
\hline Breaking at stable and trend $(\mathrm{C} / \mathrm{T})$ & 2012.Q2 & $-4.175(1)$ & -6.059 & -5.632 \\
\hline Regime Change (C / S) & 2012.Q1 & $-4.389(1)$ & -6.517 & -6.044 \\
\hline
\end{tabular}

Critical Values have been obtained from the work of Gregory and Hansen (1996).

Values provided in parenthesis show the delay amount as chosen by the Schwarz Criteria. As per the obtained results, the basic hypothesis stating that there is no cointegration relationship in the stable break model, trendy stable break model and regime model has been rejected. As per the results of the analysis, a long term cointegration relationship can be spoken of between the considered variables.

\subsection{Long Term Analysis: Prediction of Cointegration Coefficient}

By finding a long term relationship between the variables as a result of the cointegration test, long and shor term relationships can be predicted with various methods. In this work FMOLS cointegration coefficient predictions have been used which can include the structural breaks as variables. FMOLS method cointegration tests method as developed by Philips and Hansen (1990) are used for the prediction of long term coefficient prediction belonging to the independent variables where the relationship exists. FMOLS predictor is especially an effective method for remedying the deviation arising from the consecutive link and internality problem between the independent variables and error term (Nazlığlu, 2010:99). A first degree difference has been considered for each variable.

Table 7: FMOLS Results on the Prediction of Cointegration Coefficient

\begin{tabular}{|c|c|c|c|}
\hline Dependent Variable & DKR & DGAP & DSYR \\
\hline \multirow{2}{*}{ DROE } & $-0.057(0.026)^{*}$ & $-0.031(0.003)^{*}$ & $-0.032(0.026)^{*}$ \\
\hline Dependent Variable & DKR & DGAP & DSYR \\
\hline DROA & $-0.04(0.005)^{*}$ & $-0.024(0.009)^{*}$ & $-0.042(0.085)^{*}$ \\
\hline
\end{tabular}

*appropriate variable for 0.05 ve 0.01

Note: Variable is taken as 2012.Q1.

In Table 7 it has been determined that the independent variables are statistically appropriate and related on ROE and ROA both at $1 \%$ and $5 \%$ levels. 
In the model analysed for ROE; where the KR variable is increased by $1 \%$ ROE variable decreases by $5 \%$, where GAP variable is increased by $1 \%$ ROE decreases by $3 \%$ and where SYR variable is increased by $1 \%$ ROE decreases by $3 \%$. In the model analysed for ROA; where the KR variable is increased by $1 \%$ ROE variable decreases by $4 \%$, where GAP variable is increased by $1 \%$ ROE decreases by $2 \%$ and where SYR variable is increased by $1 \%$ ROE decreases by $4 \%$.

Among the independent variables KR and GAP show the credit and liquidity risk status of banks. In the event that the credit and liquidity risk status of banks are high, as per the necessities of Basel reconciliations, equity equivalent requirements of banks to be stored as liquidity increases. As known, SYR determined by Basel reconciliation shows the minimum equity amount the banks need to maintain in liquidity as per the risks they face. Increase in banks' risks shall cause an increase in the equity requirement of banks. In other words increase SYR shall mean that as per the necessities of Basel reconciliations, equity equivalent requirements of banks to be stored as liquidity increases. Therefore increase of the credits risk, liquidity risk and SYR considered as independent variables will decrease the liquid assets of banks which they may utilize as loans. Such an event will cause an increase in the capacity of banks to give out loans by decreasing their mediation activities and a decrease in their interest income which is their basic activity income. This decrease will effect the profitability of banks adversely.

In the implementation phase of the work it has been determined that in a long term analysis the credit risk, liquidity risk and SYR affects the profitability of banks (ROA and ROE) adversely.

\subsection{Short Term Analysis: Error Recovery Method}

Short term analysis has been developed by applying the FMOLS method, within the error remedy model, by using the differentiated sequences and a one term delay value (ECTt-1) of the error term sequence obtained from the long term analysis.

Table 8: Short Term Error Recovery Method Coefficient Predictions

\begin{tabular}{|l|c|c|c|c|}
\hline Dependent Variation & ECTt-I & DKR & DGAP & DSYR \\
\hline DROE & $-0.239(0.001)$ & $-0.026(0.001)$ & $-0.017(0.025)$ & $-0.029(0.013)$ \\
\hline Dependent Variation & ECTt-I & DKR & DGAP & DSYR \\
\hline DROA & $-0.294(0.000)$ & $-0.035(0.028)$ & $-0.016(0.004)$ & $-0.0271(0.026)$ \\
\hline
\end{tabular}

In Table 8 it is seen that the error recovery coefficient is applicable adversely and statistically; error remedy mechanism is working. In other words, deviations in short term of variables acting together in the long term are remedied (each year $23 \%$ regression for ROE and $29 \%$ for ROA) and the variables are getting closer to the balance value in the long term (a deviation this year, in 4 years' time). It is seen that the short term effect coefficient is decreasing in value compared to the long term, meaning that the independent variables effect the dependent variables with a lower impact in the short term but a higher effect in the long term.

\section{Conclusion}

To enable the banking audits to be more understandable, development of banking activities and alignment of national capital sufficiency calculation methods with one another the Basel Committee active under BIS has published Basel I reconciliation in 1988 and formed its most recent content in 2010 with Basel III reconciliation. Turkish banking sector which has started to apply the accepted criteria of the Basel reconciliation has started applying Basel II criteria as of 1 July 2012. Upon the announcement of Basel III reconciliation right after the implementation of Basel II reconciliation in Turkey by the basel Committee, the effects of Basel III criteria on the Turkish Banking Sector have been subject to discussion.

Basel III criteria aims to enhance the effectiveness of the auditing entities in the nations's banking systems and the transparency of the banking system. Thereby it is aimed to decrease the off the record activities in the financial system. Furthermore with the "circular capital buffer" and "Capital Preservation Buffer" applications it is also aimed to increase the resistance of banks against crisis with strong capital structures.

In this work, the effect of the necessities applied by the Basel criteria on the profitability of banks has been predicted by the Cointegration Analysis method for the long term. In the implementation part of the work; it has been determined that the credit risk, liquidity risk and SYR adversely effect the banking profitability (ROA and ROE). Increase in the credit risk, liquidity risk and SYR will cause both a decrease in the liquid assets which can be offered by the banks as loans and will also cause a decrease in the banking mediation activities. In this case the capacity of banks to grant out loans will decrease and cause a decrease in their interest income which is their basic activity income. This issue has also been tested by the analysis in the empirical part of the work. 
Within the scope of Basel III criteria the change of equity scope, increased capital necessity and application of new liquidity ratios may affect the profitability of the banks adversely. Because as a result of high liquidity necessities brought in by Basel III, banks will keep part of their sources in liquid assets in which case cause a decrease in their loan volumes. Upon the application of Basel III criteria, it is expected for the commercial customers of banks to be preferred among high credibility protfolios, low risk and low credir rate with high repayment capacity. Through this change, with respect to high credibility customers, an additional cost will not arise against the banks however as per the low credibility customers the banks' credit costs shall increase. Meaning that a bank customers with low credibility will increase the portion of risky credits in the banks' portfolios thereby even if the profitability of banks increase in the short term it will decrease in the long term.

\section{References}

Basel Committee On Banking Supervision. (1988). International Convergence of Capital Measurement and Capital Standards.

Basel Committee On Banking Supervision. (1996). Overview of The Amendment to The Capital Accord to Incorporate Market Risks.

Basel Committee On Banking Supervision. (2004). International Convergence of Capital Measurement and Capital Standards: A Revised Framework. BIS.

Basel Committee On Banking Supervision. (2010). Press Release. BIS.

BDDK (2010). Sorularla Basel III (Questions on Basel III). BDDK Yayını, https://www.bddk.org.tr/ContentBddk/dokuman/duyuru_basel_0001_53.pdf, (25.02.2016).

BDDK (2016). Türk Bankacılık Sektörü Temel Göstergeleri (Basic Implications of Turkish Banking Sector). BDDK Yayın1, https://www.bddk.org.tr/ContentBddk/dokuman/veri_0014_31.pdf, (02/10/2019).

BDDK. (2008). Basel II Uygulamasının Ertelenmesine İlişkin Basın Açıklaması (Press Release on Basel II application postponement).https://www.bddk.org.tr/ContentBddk/dokuman/duyuru_0323_01.pdf, (02/10/2019).

BDDK. (2014).Türk Bankacılık Sektörü Genel Görünümü (General Overview on the Turkish Banking Sector).

Chen, James Ming. (2014). Measuring Market Risk Under the Basel Accords: VaR, Stressed VaR, and Expected Shortfall. The IEB International Journal of Finance. Vol. 8, 184-201.

Gregory, A. W. \& Hansen, B. E. (1996). Residual-Based Tests for Cointegration in Models with Regime Shifts, Journal of Econometrics, 70, 99-126.

Official Gazette. 05.09.2013. Say1 28756. Regulation on Equity of Banks

Official Gazette. 05.09.2013. Say1 28756. The Regulation on the Measurement and Evaluation of the Capital Sufficiency of Banks.

Official Gazette. 26 October 1989. No 20324.

Official Gazette. 9 February 1995. No 22197.

Phillips, P. C. B. \& Hansen, B. E. (1990). Statistical Inference in Instrumental Variables Regression with I(1) Processes, Review of Economics Studies, 57, 99-125.

TMSF. http://www.tmsf.org.tr/intikaleeden.bankalar.tr. (25.02.2016)

Turkey Bank Association data.

Yavuz, Nilgün Çil (2006). Türkiye'de Turizm Gelirlerinin Ekonomik Büyümeye Etkisinin Testi: Yapısal Kırılma ve Nedensellik Analizi, Doğuş Üniversitesi Dergisi, 7(2), 162-171.

Yayla, Münür \& Yasemin Kaya. (2005). Basel II. Ekonomik Yansımaları ve Geçiş Süreci. BDDK ARD Çalışma Raporlar1.

Yüksel, Ayhan. (2005). Basel II'nin KOBİ Kredilerine Muhtemel Etkileri. BDDK Araştırma Yayınları.

Zivot, Eric \& Donald W.K. Andrews (1992). Further Evidence of the Great Crash, The Oil-Price Shock and The Unit Root Hypothesis, Journal of Business and Economic Statistics, 10, 251-270. 